\title{
Charting a Course on the Islamic Finance Ocean: A Survey of Islamic Insurance Literatures
}

\author{
Lukman Ayinde Olorogun, Azman Mohd Noor \\ International Islamic University, Kuala Lumpur, Malaysia
}

\begin{abstract}
The number of Muslim literates in Islamic finance and conventional finance, particularly Islamic insurance, has grown tremendously, so has the number of academic and professional articles, books, and other monographs published in Islamic insurance profession. Despite Islamic insurance uniqueness based on Islamic values and philosophies, its emancipation aimed to compete or eradicate the conventional insurance at both academic and professional levels. Those monographs that were intended to replace their conventional insurance counterpart have triggered endless debates among stakeholders on their authenticity and quality of knowledge and as well challenged their authors' authorities. Therefore, with content analysis, this survey verified whether the Islamic insurance literatures were capable of producing well-seasoned professionals of Islamic insurance. The results showed that the disputes over the available literatures might have contributed to the failure of having a standard curriculum for teaching Islamic insurance as a profession in academic at national and international levels. Review of the literatures and curriculum was recommended.
\end{abstract}

Keywords: Islamic finance, insurance literature, Islamic insurance, underwriting and rating, agency and investment

\section{Introduction}

Institutionalisation of Islamic financial institutions (IFIs) took effect immediately it was pronounced a legitimate business in Islamic laws. To simply put it, with little or non-feasibility studies, the Islamic finance community was divided into scholars and practitioners, otherwise known as operators (Al-'Anzi, 2009). These groups worked for the survival of Islamic finance concurrently. The scholars with little or non-conventional expertise was trying to justify Islamic finance legitimacy through theories on one hand. On the other hand, the practitioners, mainly with few or non-Islamic juristic knowhow on Islamic commercial laws, flagged and operated IFIs. Their conventional finance backgrounds heavily shaped their operations with many Islamic financial products mimicking its conventional counterpart (Olorogun, 2012). Notably among these traits, are Islamic finance's ancillary "Islamic insurance" handling and managing the risks exposure of individuals and entities.

Without prejudice to the Islamic insurance stakeholders' efforts, particularly academics and operators, this

Lukman Ayinde Olorogun, Ph.D., IIUM Institute of Islamic Banking \& Finance, International Islamic University, Kuala Lumpur, Malaysia.

Azman Mohd. Noor Ph.D., associate professor of Fiqh and Usul al-Fiqh, Kulliyyah of Islamic Revealed Knowledge and Human Sciences, International Islamic University, Kuala Lumpur, Malaysia.

Correspondence concerning this article should be addressed to Lukman Ayinde Olorogun, 2-6-1 Idaman Suria Condo, Jalan 10/21D, Medan Idaman, Gombak, 53100 Kuala Lumpur, Malaysia. E-mail: yinluk2000@yahoo.com. 
survey aims to evaluate the achievements of this discipline in grooming the next generations of Islamic insurance experts based on the existing literatures. This study tries to classify the existing literatures according to their major areas of exploration and sound academic arguments and establishes the gaps they filled, their impacts on the Islamic insurance educational curriculum developments in the Islamic insurance institutions, and its consequences on the students. The survey is arranged as follows: The next section briefly states development of Islamic insurance, followed by fundamental theories of Islamic insurance, agency and investment as underlying and operational models, results and analysis, and conclusions.

\section{Literature Review}

Islamic insurance augments of Islamic finances through soft services provided as risk elimination or reduction such as conventional insurance are for the conventional finance (Khan \& Joseph, 2008; Khan \& Bhatti, 2008; Siddiqui \& Mohamed, 2009; Abbas, 2011; FCA, 2013; Olorogun, 2013a). Thus, it is expected that the evolutions or developments of Islamic insurance at academic and market levels should follow the paste of its conventional counterpart. Since the inception of Islamic insurance was over 40 years ago, however, the industry is still far away from standardisation. The stakeholders, such as Annuar and Abu Bakar (2010), Bhatty (2010), Standard \& Poor's Financial Services LLC (2011), Swiss Reinsurance (2011), Visser (2012), Middle East Insurance Review (2011), Islamic Finance News (2012), Best (2013), and Olorogun (2013a), commonly reported lack of standardised practices and regulations across the regions. In addition, the operational issues, such as underwriting and rating (pricing), have attracted limited or no attention of the academics and practitioners alike (Olorogun, 2013b). It has long been proven that underwriting and rating are vital and core operational efforts to the success of conventional insurance industry (Schultz \& Bardwell, 1959).

Issues of underwriting in conventional insurance were explored by Mehr and Cammack (1980), Mehr (1979, 1986), Dorfman (1982), Light (2004), Mehr and Gustavson (1987), Bickelhaupt (1983), Rejda (1989), Trowbridge (1989), Norberg (1990), Bühlmann (1997), Schweizer (2001), Whelan (2002), and American Academy of Actuaries (2008), Macedo (2009), Berenson, Levine, and Krehbiel (2009) on theoretical aspects of rating. Excellent academic researchers, such as Arrow (1963, 1971, 1974), Raviv (1979), Bühlmann (1985), Briys, Dionne, and Eeckhoudt (1989), Rejda (1989), Green, Trieschmann, and Gustavson (1992), Luan (2001), Cummins and Mahul (2002, 2004), Liu and Yang (2004), Laeven and Goovaerts (2008), Karni (2007), Zhou, W. Wu, and C. Wu (2010), Walhin and Paris (1999), Bernard, He, Yan, and Zhou (2012), have developed various models of rating based on various mathematical and statistical methods. Similarly, British government has invested regulations in the standardization of insurance business such as life assurance Gambling act of 1774 and marine insurance act of 1906 to mention some. Islamic insurance literature has unintentionally forgot or pay limited attention to the issues of underwriting and rating which are the core aspect of insurance business.

\section{Method and Procedure}

The data mining resulted in over 100 literature selected from Islamic insurance, however, after data screening, authors retained almost 60 articles based on their originality. It was discovered that there are some sorts of rank Xeroxing among the published materials. In other words, literatures of secondary sources were excluded, i.e. literatures that merely repeated previous findings. The retained articles are classified into topical issues such as institutionalisation, operation, and regulations that are relevant to academic curriculum. Dedicated extraction and content analysis methods would be used to review and organise these literatures into 
relevant themes that are presented in simple statistics for an easy analysis. The results will be presented in percentage (\%) that are further intuitively analysed in accordance to their respective contents.

\section{Development of Islamic Insurance}

Islamic insurance constitutes a relatively new form of insurance as compared to the conventional insurance which has been in existence for more than five centuries. The creation of Islamic insurance occurred at a time when Muslim economies began concentrating their efforts on modern ways to discharge their religious obligations. New alternative ways of modern business and finance were sought in order to avoid the payment of interest, ambiguity, and any forms of gambling in all their commercial and non-commercial activities. Usury can be avoided in commercial contracts by determining a fair and justified price on the article or subject matter of a contract which satisfies both parties in the course of the exchange. Although the firmly established principles of conventional insurance also form the foundation of Islamic insurance, there is a substantial difference in their approaches, when it comes to the critical evaluation of these two forms of insurance. The nature and content of scholarly discourse on insurance rating differ in the conventional and the Islamic literature. Studies on underwriting and rating from an Islamic perspective are rare, while there is a plethora of studies to be found from the conventional perspective. Thus, the first part will focus on fundamental theory of Islamic insurance, followed by underlying operational models of Islamic insurance, i.e. agency and investment models.

\section{Fundamental Theory of Islamic Insurance}

As Islamic insurance emerged, Islamic scholars, academics, and authorities across the Muslims countries have strived to justify the necessity and relevance of Islamic insurance philosophies, values, and beliefs at both historical and contemporary levels. Islamic scholars' first task was to formulate justification for Islamic insurance from the Islamic heritage, as it has no direct reference from the original sources of Islamic laws, i.e. the Qur'an (The holy book of Islam given to Prophet Muhammad (peace be upon him)) and Sunnah (Prophet Muhammad's traditions). The scholars, in their praiseworthy efforts to articulate Islamic civilization to conventional insurance, resolved that conventional insurance is in consonant to the mediaeval Arabian system of mutual prudence (Billah, 2003; Ayub, 2007; Islamic Finance Standard Board [IFSB], 2010, 2011, 2012; Buang, 2007; Billah, 2007; Hussain \& Pasha, 2011).

The theory of mutual prudence was long used among the nomadic Arabs before the birth of Islamic civilization. Mutual prudence system was being invoked in murder cases to prevent further bloodshed (Billah, 2003; Ayub, 2007; IFSB, 2010, 2011, 2012; Hussain \& Pasha, 2011). For instance, if a man from a clan killed another man from another clan, the family of the killer were interfered by paying a ransom to the family of the killed in replace of the killer's life. The prophet endorsed this practice, because it is an act of preservation of life and maintenance of peace and harmony in the community (Billah, 2003). Preservation of life indeed is one of the major maqasid al-Shari'ah (i.e. the aims and objectives of Islamic law "Islamic Worldview") (Al-Shafi'i, 1393; Ibn Quddamah, 2004).

Juxtaposing the mutual prudence system to the conventional insurance under critical observation with dedicated analysis, mutual prudence appears and insurance systems as claimed above need vivid investigation. The insurance contract was never being invoked after death and family relation, in fact, that seems to be in opposite to the insurance contract (Mehr, 1986). From the contemporary Islamic insurance practical viewpoint, 
it is not sure that whether the Islamic insurance participants have blood relation (Olorogun, 2013a). The Islamic brotherhood that the participants claimed does not necessitate paying money for another person's crime. In fact, punishment and penalty are grounded theories in the Islamic jurisprudence and Islamic law (Ibn Najim, 1980; Al-Zuhayli, 1986; Ibn Quddamah, 2004; Ibn Hammam, 2003). Surely, however, the Islamic insurance contract is not as a result of death (i.e. murder) or injury. In fact, there are a lot that need clarifications on this issue. From the system of mutual prudence, the scholars further developed a system that would be underlying modus operandi of the Islamic insurance. Thus, they resolved in approving the usage of agency model, investment model, and the combination of agency and investment models (Al-Qurradaghi, 2004, 2009; IFSB, 2012; Mohd Noor, 2009; Muhammad, 2009; Bank Negara Malaysia, 2010, 2013; Olorogun, 2013a). However, these models under vivid scrutiny raise serious doubt about their applicability in theory and practice.

Some of those serious concerns are that conventional insurance is a protection industry, not an investment industry, the nature of Islamic insurance companies' formation does not resemble conventional mutual (Mehr \& Cammack, 1980; Mehr, 1986), stock (Mehr \& Cammack, 1980; Mehr, 1986), and cooperative companies (Rejda, 1989). However, Al-Qurradaghi (2004, 2009), Al-Qari (2009), and Al-Suwaylim (2009) classified Islamic insurance as cooperative or mutual system. With these issues, it appears that there is a need to investigate the gaps between the literature and practice of Islamic insurance. From academic viewpoint, there are conflicts of opinions in terms of the fundamental theory of Islamic insurance.

\section{Agency and Investment: Underlying and Operational Models of Islamic Insurance}

These recent discussions have explored various aspects of Islamic insurance, such as its scope and definition, fundamental concepts, benefits, mechanisms, and models, as for example, agency, investment, or a combination of both (Yusof, 1991; Billah, 2003; Maysamia \& Williams, 2006; Abdul Wahab, Lewis, \& Hassan, 2007; Rashid, 2007; Khan \& Joseph, 2008; Loo, 2010; Hassan, 2009; Abdul al-Hamid, 2009; Al-Qurradaghi, 2009; Al-Shubayli, 2009; Mohd Noor, 2009; Asmak, 2009; Azman, 2009; Abdul Kader, Adams, \& Hardwick 2010; Annuar \& Abu Bakar, 2010; Khan, Alam, Ahmad, Iqbal, \& Ali, 2011; Fauzilah \& Abdul Razak, 2011).

When the contract is based on agency, the terms of the deal recognised the participants as the "principal" and the Islamic insurance operators as the "agent". The participants are the owners of the Islamic insurance funds and the operator is the agent employed to manage the funds on behalf of the participants (Al-Qurradaghi, 2004, 2009; Al-Shubayli, 2009; Al-Suwaylim, 2009; Hidir, 2009; Al-Sanad, 2009; Mohd Noor, 2009; Farooq Chaudhry, Alam, \& Ahmad, 2010). Under normal circumstances, that is, normal agency in English common law (Jensen \& Meckling, 1985; Fama \& Jensen, 1983) and Islamic law (Ibn Quddamah, 2004; Ibn Hammam, 2003), the principal possesses the right and power to dictate the terms of the contract as well as agency fees. In the contrary, currently, the Islamic insurance operator possesses the power to fix price or amount each participant will contribute and dictate who is qualified to be accepted into a certain pool of fund (Olorogun, 2013a). Furthermore, the operator uses the funds as his wishes, in any manner or at any time (Olorogun, 2013a). Similarly, the "investment model" also raises questions concerning the purpose of the creation of Islamic insurance and what the consumers really need (Olorogun, 2013a). Bearing in mind that this industry intended to eradicate or compete with the conventional insurance.

There are further arguments that Islamic insurance scheme should be extended to investment. The proponents, such as Mohd Noor (2009), opined that the participants needed more than protection. Thus, he suggested investment linked Islamic insurance scheme. While this sounds genuine and acceptable, 
professionally investment link insurances are purely and fundamental integral part of conventional life assurance schemes that are longer term contracts. Though the article achieved its purpose which is the Islamic law evaluation nonetheless, it shows how heavily the literatures are on Islamic law "legal aspects" than the core activities of conventional insurance.

Another inconsistence relationship between the literature and practice of Islamic insurance which had up-stretched the concern of rating agencies, such as Standard \& Poor's Financial Services LLC (2011) and Best (2013) etc., was the issue of the participant's contribution technically called "donation (charity)". The Accounting and Auditing Organization for Islamic Financial Institutions (AAOIFI) Islamic law standard 26, Section 1, No.5, however, proclaims the participants' contributions as "compulsory donation (charity)" (AAOIFI, 2007). These shortcomings have shaped Islamic insurance practices. It also created endless academic writings on the Islamic insurance sub standardisation which research methods expert Bernard (1995) posited. Perhaps, this is one of the major problems, which led to lack of underwriting and rating's literature from Islamic insurance viewpoint. A great attempt by Mohd Noor (2010) to address this issue of underwriting proved that there is little or no existing literature on these cores "underwriting and rating" of conventional insurance.

A number of Muslim scholars have individually, impliedly, and expressly justified the legitimacy of Islamic insurance industry and participated in the formulation of its rules and regulations. Notably among these scholars' contributions are al-Qurradaghi $(2004,2009)$ and Hidir (2009) who established the Islamic legal rulings of Islamic insurance and its formation as "cooperative insurance", particularly its underlying operatives models of agency and investment. Al-Qari (2009) in addition, addressed the Islamic legal rulings' on the profits earned by the Islamic insurance industry. Al-Sanad (2009), nevertheless, discussed the salient weaknesses of these insurances in the light of Islamic legal rulings, which is eminent, despite their permissibility under AAOIFI rules and regulations. While al-Suwaylim (2009) positively asserted this idea of profit making, however, he argued that making profits at the expense of other people is strictly prohibited in the Islamic cannons.

In the same thought, Hidir (2009) expressed dismay about the disparities of methods and forms of profit distributions in the Islamic insurance industry across regions. This was in response on the methods of $10 \%$ profit return on the investment model to participants and 50\% return of profit to the shareholders applied in Saudi Arabia and Kuwait respectively. Hidir concluded that there is no justification for these practices in Islamic laws. Al-Jurf (2009) likewise, criticised the Saudi Arabia's Islamic insurance profit distribution as a method of neglecting the participants' rights. Even the international Islamic finance regulatory body "AAOIFI's" Islamic law standard 26, Section 1, No.5 authorised the operator to request the participants for additional donations. It further authorised the operator to institute legal action against any erring participants (AAOIFI, 2007).

Moreover, the practice is to advance loan from the shareholder's fund. Hidir (2009) further stated that when there is no return, the shareholders bear the risk and losses that may arise in the course of investment. Best (2013) questioned the Islamic law basis for continuous advancement of benevolent loan from the shareholder's fund to the participants without mechanism of paying back the loan. Thus, it suffices to conclude that the relationship among parties in Islamic insurance is based on compelled modus Vivendi, not mutual relationship as claimed in the definition of Islamic insurance. Abdul Wahab et al. (2007) and Al-Shubayli (2009) researched the close relationship existing between Islamic insurance and endowment. 
Among the most distinguished and respectable scholars of Islamic finance are Al-'Anzi (2009) and Al-Dawsari (2009), who are critical of the Islamic insurance. Al-'Anzi particularly did not hesitate to criticize the competency and the ultimate motives of the authors of the main body of publications that circulated on Islamic insurance. In his opinion, the majority of publishing authors do not have the competency to write authoritatively on this matter. He also pointed out that there did not exist a single academic institution in Saudi Arabia and other Muslim nations, which offered insurance as an object of serious academic research and study. Likewise, Al-Dawsari (2009) ascertained the struggle cooperative insurance fought between lofty theory and actual practice. He bluntly asserted that comparing it to Islamic insurance was just "the changing of names". In his opinion, there existed no difference between Islamic insurance and its conventional counterpart "save the trademark". He explained that this disturbing state of affairs was due to the lack of proper deliberation and sound academic research, which led to the failure of Islamic insurance. Among the valuable observations made by Al-Jurf (2009) in his study were the question of the legitimacy of gift and its actual difference from simple profit. To extend Al-Jurf's argument, the researcher raises concern that whether someone can be given a gift from his own personal property. This anxiety was based on the scholars' such as Al-Qurradaghi (2009) asserted that the funds of Islamic insurance belong to the participants.

\section{Results and Analysis}

\section{Results}

In all papers, reviewed common traits on issues addressed were on various aspects of Islamic insurance such as regulations, operations, market reports, and technical corrections. Of the total number, $44 \%$ were concentrated on regulations of Islamic insurance, regardless whether they were regional or nationally motivated or sensitive. This included Islamic legal rulings and institutional "AAOIFI Islamic law standard, IFSB regulations etc.. Twenty-eight percent were on operational issues of Islamic insurance models, i.e. agency, investment, and combinations of agency and investment models, which spread across issues, such as fundamental theories justifying its legitimacy, accounting, and managerial practices including regional and national parities of accounting practices, the industry's compatibility with conventional insurance, and consumers' perspectives etc.. Similarly, 22\% addressed markets' performances. Six percent began discussions on revisiting earlier literatures and suggestion of amendments that are relevant.

\section{Analysis}

Unlike its conventional counterpart, ${ }^{1}$ Islamic insurance literatures reviewed showed that it was never been practiced before its regulations. In fact, Al-'Anzi (2009) agitated that the industry was instituted immediately it

\footnotetext{
${ }^{1}$ Notably, conventional insurance was over two centuries in practice and academic alike. Over the years, continuous writings and practical experiences of stakeholders have paid for its standardization at both market and academic levels. Thus, enough literature is available on its technical and core operational aspects of underwriting (Schultz \& Bardwell, 1959; Bickelhaupt, 1983; Mehr, 1986; Rejda, 1989; Beekman, 1990) and rating (pricing) (Arrow, 1963, 1971, 1973, 1974; Raviv, 1979; Bühlmann, 1985, 1997; Trowbridge, 1989; Schweizer, 2001; Whelan, 2002; Light, 2004; Cummins \& Mahul, 2002, 2004; D'arcy, 2005; Laeven \& Goovaerts, 2007; Zhou et al., 2010; Bernard et al., 2012). Regulations are well documented through ages globally. Most of these regulations were developed or formed from the British's insurance laws, such as Life Assurance act of 1774 (U.K. Government, 1774) and Marine insurance act of 1906 (U.K. Government, 1906). The well documented aspect of institutionalization of conventional insurance began at Edward's coffee shop in London, which marked the birth of Lloyds' underwriters (Schultz \& Bardwell, 1959; Bickelhaupt, 1983) and at the same time, the first actuarial model of life assurance premium's calculation was established, for example, the Nigerian Road Traffic Act of 1945 (RTA) was adopted from its colonial RTA 1930's counterpart. For more kindly see Goovaerts and De Vylder, 1979; Briys et al., 1989; Albrecht, 1992; Briys and De Varenne, 2001; Luan, 2001; Froot, 2001; Rotar, 2007; Laeven and Goovaerts, 2007; and Conniffe, 2007.
} 
was pronounced to be Islamically permissible by the council of higher scholars in Saudi Arabia without any prior feasibility study. There was thus, no market or academic experience before the establishment of Islamic insurance particularly in Saudi Arabia. Perhaps, this is the single reason why most of the available literatures were on legal aspects of Islamic insurance. Another shared notion in the Islamic insurance literatures was the erroneous fundament theory of assumed resemblance between conventional insurance and contract of mutual prudence (Olorogun, 2013a). Huge numbers of that literatures tautologised around its permissibility under Islamic law. Another issue of focus was about the operational models of agency and investment. These models have been criticised and blamed for all inconsistences and considered as wrong basis of establishing Islamic insurance contracts (Alpen Capital, 2010; Annuar \& Abu Bakar, 2010; Standard \& Poor's Financial Services LLC, 2011; Best, 2013).

Likewise, Olorogun (2013b) evaluated the diffusion of agency theory into Islamic insurance agency operational model and found that the agency contract was just a claim. The results further showed that the AAOIFI standard gave the agent "the operators" right and power to institute legal actions against the principals "the participants or contributors (owners' of funds)". Furthermore, tenacious criticisms from the markets' reporters about the Islamic insurance industry practices and regulation disparities across regions were common. Even Annuar and Abu Bakar (2010) found disparity of accounting and auditing policies among Islamic insurance companies in Malaysia. It is clear at this point that Islamic insurance proponents have asserted many efforts; nevertheless, it is not enough. With erroneous theory, such as mutual prudence theory, definitely the Islamic insurance profession would never produce sound academic professionals. The erroneous theory was compounded by wrong concept of agency model of contract. Above all, the regulations' disparity within and across the regions will surely hamper production of experts in Islamic insurance. Mohd Noor (2009) made a proposal that Islamic insurance scheme should be extended beyond protection to investment linked scheme, however, in his opinion, there is no clear indication of separation between family and general Islamic insurance as regards to the use of investment linked program. For half a century of its existence, Islamic insurance curriculum has no specialisation compared to its counterpart that has developed into underwriter/insurance and actuarial professions with insurance having three major specializations, i.e. general insurance, life assurance, and marine and aviation insurance (Olorogun, 2014).

There is no doubt that lofty relationship exists between the academic and the practices of Islamic insurance. In the same direction, there was no expertise in the area of underwriting and rating in Islamic insurance, because there is no curriculum to teach such professional sensitive areas. Putting in mind that underwriting and rating were the backbone of conventional insurance. In fact, there are no institutions "university or polytechnic" that have department of insurance in Malaysia, the hub of Islamic finance. The researcher posited that knowledge of insurance is the pre-requisite for building well-seasoned Islamic insurance experts. To be fair to the stakeholders, it is reasonable to express that "the intended and determined Islamic insurance operator" must possess both insurance and Islamic jurisprudence knowledge. Thus, Islamic insurance experts have more responsibilities compared to their conventional insurance experts. This would make the operators be conscious of their accountability to Allah and to the other stakeholders. The prominent questions that need to be answered by all stakeholders are: (1) How Islamic insurance would develop and compete with conventional insurance without sound and well-seasoned experts in the areas of underwriting and rating at both academic and practice, (2) how it would develop with multiple regulations and erroneous underlying contractual models standardisation in occurrence. 


\section{Conclusions}

This survey brought to light that there were no Islamic insurance experts produced in Islamic insurance across the Islamic finance academic institutions for half a century ago. It is fair to conclude that there is a serious and urgent need for designing a special curriculum that would combine conventional insurance and Islamic jurisprudence for the Islamic finance academic institutions. This would consequently produce the needed experts particularly in the area of underwriting (insurer) and rating (actuary). Presently, to the best knowledge of the researcher, the general certificate issued to those graduating from those institutions is merely designated as qualified in "Islamic banking and finance" which is too general and ambiguous.

Rather than agitating for the markets' or funds' growth of the Islamic insurance profession as common in most of the literatures reviewed, efforts should be channelled to the development of the academic professions. It is a long-term investment. It is obvious that rating in conventional insurance is yet to be equitable. Thus, there is a need for Islamic insurance to stereotype its surrogate roots, i.e. conventional insurance. In addition, the existing body of research does not combine conventional theory and Islamic theory and attempt to synthesize the two approaches and frameworks. All consulted academic works on the development of rating models are strictly conventional and the discussion of underwriting consideration remained strictly confined to the conventional perspective. Conversely, regulators' resolutions and modern Muslim views on Islamic insurance were limited to theory and totally from legal viewpoints.

Other set of literatures were empirical studies seeking views of consumers about the products and professional knowhow of the operators. However, Olorogun (2013a, 2013b) found that some of those works on legal issues were proved inaccurate based on the fundamental erroneous concepts. Likewise, Annuar and Abu Bakr (2011) found various accounting practices among Malaysian's Islamic insurance operators. Conclusively, available literatures on Islamic insurance are not sufficient both in quality and quantity to breed a professional of Islamic insurance. In other words, they are not academically sound and well-seasoned to induce the knowledge of Islamic insurance into a nonprofessional. In summary, the industry simply needs a good hearty helping, clear, and well-seasoned perspective with a side order of honesty from all stakeholders" (the Islamic Globe, 2012). The Islamic Globe (2012) and Siddiqui (2013) laid the blames of current states of affairs in Islamic financial industry on acts of alacrity and unreflected haste.

\section{References}

Abbas, R. (2011). Challenging takaful norms. Middle East Insurance Review, 6(6), 58-59.

Abdul al-Hamid, N. (2009). Taqyim Tä̈biqat wa Tajarub al-Ta'min al- Ta'awuni. Proceedings from International Islamic Bureau for Economics and Finance's Conference. Retrieved from http://www.ibisonline.net/Research_Tools/Publication /PublicationSearchPage.aspx?Mode=RC

Abdul Kader, H., Adams, M., \& Hardwick, P. (2010). The cost efficiency of takaful insurance companies. The International Association for the Study of Insurance Economics, 35, 161-181.

Abdul Wahab, A., Lewis, M. K., \& Hassan, M. K. (2007). Islamic takaful: Business models, Shariah concerns, and proposed solutions. Thunderbird International Business Review, 49(3), 371-396.

Accounting and Auditing Organization for Islamic Financial Institutions [AAOIFI]. (2007). Shari'ah standards. Bahrain: Dar al-Istithmar.

Al-‘Anzi, F. M. (2009). Mu'awiqat Øana'ah al-Ta'min al-Ta'awuni bi al-Mumlakah al-'Arabiyyah al-Sa'udiyyah. Retrieved from http://www.ibisonline.net/Research_Tools/Publication/PublicationSearchPage.aspx?Mode=RC

Albrecht, P. (1992). Premium calculation without arbitrage? Astin Bulletin, 22, 247-254. 
Al-Dawsari, M. A. (2009). Al-Ta'min al-Ta'awunibayna 'AÍlam al-Nazariyyahwa al-Awham al-Waqi'. Proceedings from International Islamic Bureau for Economics and Finance's Conference. Retrieved from http://www.ibisonline.net/Research_Tools/Publication/PublicationSearchPage.aspx?Mode=RC

Al-Jurf, M. S. (2009). Taqyim 'AnzimahwaWasa'iq al-Ta'min al- Ta'awuni fi al-Mamlakah al-'Arabiyyah al-Sa'udiyyah. Proceedings from International Islamic Bureau for Economics and Finance's Conference. Retrieved from http://www.ibisonline.net/Research_Tools/Publication/PublicationSearchPage.aspx?Mode=RC

Alpen Capital. (2010). GCC Takaful industry report. Retrieved from www.alpencapital.com/industry-reports.htm

Al-Qari, A. M. (2009). Al-Fa'id Al-Ta'min. Proceedings from International Islamic bureau for economics and finance's conference. Retrieved from http://www.ibisonline.net/Research_Tools/Publication/PublicationSearchPage.aspx?Mode=RC

Al-Qurradaghi, A. M. (2004). Al-Ta'min al-Islami: Dirasah Fiqhiyah Ta'siliyyah Muqaranah bi al-Ta'min al-Tijari. Bayrut: Sharkah Dar al- Basha'ir al-Islamiyyah.

Al-Qurradaghi, A. M. (2009). Al-Ta'min al-Ta'awuni mahiyyatuhu wa Dawabituhu wa Mu'awiqatuhu: Dirasah Fiqhiyyah 'Iqtisadiyyah. Proceedings from International Islamic Bureau for Economics and Finance's Conference. Retrieved from http://www.ibisonline.net/Research_Tools/Publication/PublicationSearchPage.aspx?Mode=RC

Al-Sanad, A. A. (2009). Al-Dawabit wa al-Ma'ayir al-Shar'iyah lil al-Ta'min al-Ta'awuni. Proceedings from International Islamic Bureau for Economics and Finance's Conference. Retrieved from http://www.ibisonline.net/Research_Tools/Publication/PublicationSearchPage.aspx?Mode=RC

Al-Shafi'i, M. I. (1393). Al- 'Umm. Bayrut: Dar al-Ma'rifah.

Al-Shubayli, Y. A. (2009). Al-Ta'min al-Takafuli min Khilal al-Waqaf. Proceedings from International Islamic Bureau for Economics and Finance's Conference. Retrieved from http://www.ibisonline.net/Research_Tools/Publication/PublicationSearchPage.aspx?Mode=RC

Al-Suwaylim, S. I. (2009). Waqafat fi Qadiyah al-Ta'min. Proceedings from International Islamic Bureau for Economics and Finance's Conference. Retrieved from http://www.ibisonline.net/Research_Tools/Publication/PublicationSearchPage.aspx?Mode=RC

Al-Zuhayli, W. (1986). 'Usul al-Fiqh al-Islami wa Adillatuh. Suriyyah: Dar al-Fikr.

American Academy of Actuaries. (2008). Qualification standard for actuaries issuing statements of actuarial opinion in the United State: Including continuing education requirements. Washington, D.C.: American Academy of Actuaries.

Annuar, H. A., \& Abu Bakar, N. B. (2010). Issues on Takaful affecting the choice of accounting policies: A case study of two takaful companies in Malaysia. International Business Research, 3(3). 187-193.

Arrow, K. J. (1963). Uncertainty and the welfare economics of medical care. America Economic Review, 53(5), 941-973.

Arrow, K. J. (1971). Essays in the theory of risk bearing. Chicago: Markham.

Arrow, K. J. (1973). Optimal insurance and general deductibles. A report prepared for office of economic opportunity. Santa Monica: Rand.

Arrow, K. J. (1974). Optimal insurance design and general deductible. Scandinavian Insurance Journal, 1, 1-42.

Asmak, A. R. (2009). Exploring Shari'ah views on the practice of takaful company reinsuring with reinsurance company. Proceeedings from ISRA SharỄNah Conference on Takaful (ISC2009).

Ayub, M. (2007). Understanding Islamic finance. London: John Wiley \& Sons Ltd..

Azman, I. (2009). Nomination and Hibah issues in takaful industry. Proceeedings from ISRA SharỄ̃ah Conference on Takaful (ISC2009).

Bank Negara Malaysia. (2010). Conceptual paper-guidelines on takaful operational framework. Retrieved from www.bnm.gov.my

Bank Negara Malaysia. (2013). Islamic financial services act. Retrieved from www.bnm.gov.my/documents/act/en_ifsa.pdf

Beekman, J. A. (1990). An alternative premium calculation method for certain long-term care coverages. Actuarial Research Clearing House, 2, 179-190.

Berenson, M. L., Levine, D. M., \& Krehbiel, T. C. (2009). Basic business statistics: Concept and application (11th ed.). New Jersey: Pearson, Prentice Hall.

Bernard, C., He, X. D., Yan, J., \& Zhou, X. Y. (2012). Optimal insurance design under rank-dependent expected utility. Retrieved from http://ssrn.com/abstract=1883519

Bernard, H. R. (1995). Research methods in anthropology: Qualitative and quantitative approaches. Walnut Creek: AltaMira.

Best, A. M. (2013). Regulatory review: GCC takaful regulation lag market growth, creating uneven playing field. Retrieved from www.ambest.com/resources/takaful_review.pdf 
Bhatty, A. (2010). The growing importance of takaful insurance (A Working paper presented at Asia Regional Seminar, OECD and Bank Negara Malaysia under the Sponsorship of the Government of Japan, Kuala Lumpur, 23-24 September).

Bickelhaupt, D. L. (1983). General insurance (11th ed.). Homewood: Richard D. Irwin, Inc..

Billah, M. M. (2003). Islamic and modern insurance: Principles and practices. Kuala Lumpur: Ilmiah Publishers.

Billah, M. M. (2007). Islamic banking and the growth of takaful. In M. K. Hassan, \& M, K. Lewis (Eds.), Handbook of Islamic banking (pp. 401-418). Northampton: Edward Elgar.

Briys E., \& De Varenne, F. (2001). Insurance from underwriting to derivates: Asset liability management in insurance companies. New York: John Wiley \& Sons, Ltd..

Briys, E., Dionne, G., \& Eeckhoudt, L. (1989). More on insurance as a Giffen good. Journal of Risk and Uncertainty, 2, 415-420.

Buang, A. H. (2007). Role of takaful in social and economic development. Proceedings from the 3rd International Convention on Takaful and Retakaful, Kuala Lumpur.

Bühlmann, H. (1985). Premium calculation from top to down. Astin Bulletin, 5(2), 89-101.

Bühlmann, H. (1997). The actuary: The role and limitations of the profession since the mid-19th century. Astin Bulletin, 27(2), 165-171.

Conniffe, D. (2007). The flexible three parameter utility function. Annals of Economics and Finance, 8(1), 57-63.

Cummins, J. D. \& Mahul, O. (2002). Optimal insurance with divergent beliefs about insurer total default risk. Retrieved from www.huebnergeneva.org/documents/CumminsMahul

Cummins, J. D., \& Mahul, O. (2004). The demand for insurance with an upper limit on coverage. Journal of Risk and Insurance, 71, 253-264.

D'arcy, S. P. (2005). On becoming an actuary of the fourth kind. Proceedings from the Casualty Actuarial Society XCII (177), pp. $745-754$.

Dorfman, S. M. (1982). Introduction to insurance (2nd ed.). Englewood Cliffs: Prentice-Hall, Inc..

Fama, E., \& Jensen, M. (1983). Separation of ownership \& control. Journal of Law \& Economics, 26(2), 301-326.

Farooq, S. U., Chaudhry, T. S., Alam, F., \& Ahmad, G. (2010). An analytical study of the potential of takaful companies. European Journal of Economics, Finance and Administrative Sciences, 20, 54-75.

Fauzilah, S., \& Abdul Razak, K. (2011). The effects of personality factors on sales performance of takaful (Islamic insurance) agents in Malaysia. International Journal of Business and Social Science, 2(5), 259-265.

Financial Conduct Authority. (2013). Glossary: Guidance on the glossary of definitions handbook. Retrieved from www.fca.org.uk/static/documents/handbook-releases/glossary136.pdf

Froot, K. (2001). The market for catastrophe risk: A clinical examination. Journal of Financial Economics, 60, 529-571.

Goovaerts, M. J., \& De Vylder, F. (1979). A note on iterative premium calculation principles. Astin Bulletin, 10, 326-329.

Greene, M. K., Trieschmann, J. S., \& Gustavson, G. S. (1992). Risk \& insurance (8th ed.). Cincinnati: South-West Publishing Co..

Hassan, Z. (2009). Islamic finance education at the graduate level current state and challenges. Islamic Economic Studies, 16(2), 1-29.

Hidir, M. H. (2009). Al-Fa'id al-Ta'min fi Sharkat al-Ta'min al-Islami. Proceedings from International Islamic Bureau for Economics and Finance's Conference. Al-Riyadh: Retrieved from http://www.ibisonline.net/Research_Tools/Publication/ PublicationSearchPage.aspx?Mode=RC

Hussain, M. M., \& Pasha, A. T. (2011). Conceptual and operational differences between general takaful and conventional insurance. Australian Journal of Business and Management Research, 1(8), 23-28.

Ibn Hammam (2003). Fatih al-Qadir. KSA: Dar Alim al-Kutub.

Ibn Najim, Z. I. (1980). Al- 'Ashbah wa al-NaĐa'r. Bayrut: Dar al-Kitab al-'Ilmiyyah.

Ibn Quddamah, M. (2004). Al-Mughni. Cairo: Dar al-Hadith.

Islamic Finance News. (2012). The global takaful outlook. Retrieved from www.islamicfinancenew.com

Islamic Finance Standard Board. (2010).Standard on solvency requirements for (takaful) Islamic insurance industry. Retrieved from www.ifsb.org/standard/IFSB-11\%20-\%20Standard\%20on\%20Solvency

Islamic Finance Standard Board. (2011). Guidance note on the recognition of ratings by external credit assessment institution on takaful. Retrieved from www.ifsb.org

Islamic Finance Standard Board. (2012). Standard on risk management for takaful (Islamic insurance) undertakings. Retrieved from ifsb.org/.../IFSB\%20ED-14\%20Risk\%20Management\%20for\%20Takafu

Jensen, M. C., \& Meckling, W. H. (1976). Theory of the firm: Managerial behavior, agency costs and ownership structure. Journal of Financial Economics, 3(4), 305-360. 
Karni, E. (2007). On optimal insurance in the presence of moral hazard. Retrieved from citeseerx.ist.psu.edu/viewdoc/download?doi=10.1.1.170.6455

Khan, M. M., \& Bhatti, M. I. (2008). Islamic banking and finance: On its way to globalization. Managerial Finance, 34(10), 708-725.

Khan, M. M., Alam, H. M., Ahmad, N., Iqbal, M. S., \& Ali, S. (2011). Comparative analysis of Islamic and prevailing insurance practices. International Journal of Business and Social Science, 2(10), 282-286.

Khan, M., \& Joseph, B. (2008). Islamic insurance: A competitively priced, ethical product with potentially widespread appeal. The Americas Insurance digest, 14, 10-13.

Laeven, R. J. A., \& Goovaerts, M. J. (2008). Premium calculation and insurance pricing. Chicheste: John Wiley \& Sons Ltd.

Leng, C. \& Meier, U. B. (2002). Analysis of multi-national underwriting cycles in property-liability insurance. Journal of Risk Finance, 7(2), 146-159.

Light, D. (2004). Transforming underwriting: From risk selection to portfolio management. Retrieved from www.gobookee.org/underwriting-and-portfolio-management

Liu, C. S., \& Yang, H. (2004). Optimal investment for an insurer to minimize its probability of ruin. North American Actuarial Journal, 8(2), 11-31.

Loo, M. (2010). Attitudes and perceptions towards Islamic banking among Muslims and Non-Muslims in Malaysia: Implications for marketing to baby boomers and X-generation mark. International Journal of Arts and Sciences, 3(13), 453-485.

Luan, C. (2001). Insurance premium calculations with an anticipated utility theory. Astin Bulletin, 3(1), 23-35.

Macedo, L. (2009). The role of the underwriter in insurance. Retrieved from siteresources.worldbank.org/.../Role_of_Underwriter_Insurance.pdf

Maysamia, R. C., \& Williams, J. J. (2006). Evidence on the relationship between takaful insurance and fundamental perception of Islamic principles. Applied Financial Economics Letters, 2, 229-232.

Mehr, R. I. (1979). Irwin programmed learning aid series in life insurance. Homewood: Learn System Company.

Mehr, R. I. (1986). Fundamentals of insurance (2nd ed.). Homewood: Richard D. Irwin, Inc..

Mehr, R. I., \& Cammack, E. (1980). Principles of insurance. Homewood: Richard D. Irwin, Inc..

Mehr, R. I., \& Gustavson, S. G. (1987). Life insurane: Theory and practice (4th ed.). Plano: Business Publications, Inc..

Middle East Insurance Review (2011). Challenging takaful norms. MICA (P), 6(6), 58-59.

Mohd Noor, A. (2009). A Shari'ah compliance assessment on takaful investment link. Journal of Islamic Economic Studies, IRTI, IDB, 17(1), 1-30.

Mohd Noor, A. (2010). Underwriting and managing risks in takaful (A Working paper presented in Seminar on Insurance and Risk in Asia Pacific, Kyoto International Community House, 24th September).

Muhammad, S. H. H. (2009). Øiyag 'Idarah Mukhaatir wa 'Istithmar 'AqsaÏ al-Ta'min al-Ta'awuni. Proceedings from International Islamic bureau for economics and finance's conference. Retrieved from http://www.ibisonline.net/Research_Tools/Publication/PublicationSearchPage.aspx?Mode=RC

Norberg, R. (1990). Actuarial statistics: The European perspective. Proceedings from The Third Int. Conference on Teaching Statistics: Teaching Statistics Beyond School Level.

Olorogun, L. A. (2012). A critical evaluation of the compatibility between traditional and contemporary applications of murabahah transactions. AIJSS, 1(1), 32-38.

Olorogun, L. A. (2013a). Critical evaluation of fundamental theoretical concept of Islamic insurance "takaful". Asian Journal of Research in Banking \& Finance, 3(12), 39-51.

Olorogun, L. A. (2013b). An evaluation of diffusion of agency theory in Islamic insurance definition and wakalah model operation. Asian Journal of Research in Banking \& Finance, 3(12), 52-59.

Olorogun, L. A. (2014). Translating the takaful "Islamic insurance": An analytical approach. Journal of Social Science Research, 3(3), 395-401.

Rashid, S. K. (2007). Islamization of insurance-A religio-legal experiment in Malaysia. In M. K. Hassan, \& M. K. Lewis (Eds.), Islamic finance. The international library of critical writings in economics. Northampton: Elgar Reference Collection.

Raviv, A. (1979). The design of an optimal insurance policy. American Economic Review, 69, 84-96.

Rejda, G. E. (1989). Principles of Insurance (3rd ed.). Illinois: Scott, Foresman and Company.

Rotar, V. I. (2007). Actuarial models: The mathematics of insurance. New York: Chapman \& Hall/CRC, Taylor \& Francis Group.

Schultz, R. E., \& Bardwell, E. C. (1959). Property insurance. New York: Holt, Rinehart \& Winston. 
Schweizer, M. (2001). From actuarial to financial valuation principles. Insurance: Mathematics and Economics, 28, 31-47

Siddiqui, R. (2013). Lessons from Hiking for Islamic finance. Retrieved from http://www.themalaysianinsider.com/opinion/article/lessons-from-hiking-for-islamic-finance

Siddiqui, S., \& Mohamed, S. (2009). Contemporary developments and growing options in Islamic wealth management within North America and beyond. In A. D. Humayon, \& F. M. Umar (Eds.), The chancellor guide to the legal and Shari'ah aspects of Islamic finance. London: Chancellor Publications.

Standard \& Poor's Financial Services LLC. (2011). Ethics into insurance. The Islamic Globe, 34, 1-3.

Swiss Reinsurance. (2011). Islamic insurance revisited. Kuala Lumpur: Swiss Reinsurance Company Ltd..

The Islamic Globe. (2012). Roadmap to where? Retrieved from http://www.theislamicglobe.com/index.php/opinion/1320-roadmap-to-where

Trowbridge, C. L. (1989). Fundamental concepts of actuarial science. Retrieved from www.actuarialfoundation.org/research_edu/fundamental.pdf

U.K. Government. (1774). Life assurance act 1774. Retrieved from www.legislation.gov.uk/apgb/Geo3/14/48/contents

U.K. Government. (1906). Marine insurance act of 1906. Retrieved from www.legislation.gov.uk/ukpga/Edw7/6/41/contents

Visser, H. (2012). Islamic finance: Aims, claims and the realities of the market place. In A. Rexha, \& S. Badiani (Eds.), Ethical investment study: Social responsibility for the gulf investment (pp. 25-38). London: Arab Financial Forum.

Walhin, J. J., \& Paris, J. (1999). Excess of loss re-insurance with reinstatements: Premium calculation and ruin probability of the cedent. Retrieved from http://www. Springerlink.con/content

Whelan, S. (2002). Actuaries' contributions to financial economics. Proceedings from Actuarial Teachers \& Researchers Conference, Christchurch, Oxford.

Yusof, M. F. (1991). The concept and working system of takaful. London: Institute of Islamic Banking and Insurance.

Zhou, C., Wu, W., \& Wu, C. (2010). Optimal insurance in the presence of insurer's loss limit. Insurance: Mathematics and Economics, 46, 300-307. 